\title{
The Impact of the Family Policy on the Transformation of Gender Roles in the Professional and Private Spheres on the Example of German Society
}

\author{
Polina V. Sazonova \\ Tomsk State University, 36 Lenin Ave., Tomsk 634050, Russian Federation; E-mail: sazonovapv@gmail.com
}

\author{
Doi:10.5901/mjss.2015.v6n6s1p546
}

\begin{abstract}
This article is an attempt to analyze the impact of different models of the family policy on the distribution of the tasks in paid labour and family economy between men and women. The example of Germany which experienced multiple shifts in its policy direction in the recent decades, provides rich material for cultural and historical comparison. It is argued that modern family policy should be designed as a flexible set of norms that reflect the dynamics of the social changes and recognize the diversity of an individual's configuration of a biographical way, family values and reproductive patterns. In terms of methodology the author proves the fruitfulness of the combination of statistics and biographical methods of sociological research, which focused on the changes of social phenomena and norms.
\end{abstract}

Keywords: family policy, gender order, public and private spheres, work-life balance, Germany

\section{Introduction}

Within the framework of any society, we can observe a relatively stable gender order submitted by the historically conditioned patterns of relationship between men and women (Connell, 1987: 98-99). Deconstructive analysis of the gender order allocates public and private spheres: in the public sphere gender relations and hierarchies in the politics, the economy and the labor market are analyzed; in the private sphere family, marriage and intimate sexual relationships are objectified.

There are multi-dimensional dynamic relationships between the public and the private space, and the place of their collision is a family - the central institution in the life of an individual. The family is the social system where we can observe interaction between partners who are trying to find the best way of living together, provide each other with material, social and emotional support (Lange, Jurczyk, 2010).

It is important to underline that the sphere of family relations is not only reflects the prevailing gender order in the society, but also reacts sensitively to social changes. Following the developments in family behavior strategies can provide fruitful material for the researcher, who aims to evaluate the progress and the consequences of the transformation of the society in its various dimensions.

The one of the key features in the structure of modern societies favor the premise that all people of working age are in paid work, and the longer the better (Daly, 2011). So, the family and the paid work are two essential elements of any biographical portrait of modern individual, and they are experienced mostly in a conflict-ridden relationship rather than in the desired balanced combination. I argue that women are acutely forced to deal with the problem of finding worklife balance, while they continue to perform most of the unpaid care work in housekeeping, raising children, caring for the sick and elderly family members. This explains the increasing importance of time-management for the quality of a woman's life in its subjective (satisfaction, happiness) and objective (health, career, completeness of private life) dimensions (Rozhdestvenskaya, 2012: 59; see also Klammer et al., 2000, Janczyk et al., 2003).

The combination of paid work and care is unique for each society and builds on national and cultural patterns that govern socially approved role of breadwinner in the family and the involvement of public institutions in the implementation of care. I adhere to the hypothesis that at the level of a particular household, this is reflected in a specific division of labor that maximizes the material, social and emotional benefits for all its members, based on institutional and cultural context of the society and individual socio-demographic characteristics of the partners: the class, the level of education, and the family composition (Pfau-Effinger, 1998; Hofäcker et al., 2013; Stoilova et al., 2011).

Nowadays, the government of all modern countries help families to some extent to cope with their daily concerns and challenges, conducting family policy (Cheal, 2008: 137), which is aimed as a complex legal, economic and social support for families in carrying out their social functions associated with the birth and the raise of the children, as well as 
the care for disabled family members. At the same time, it is necessary to bear in mind the multi-dimensional and systematic architecture of the family policy, which is correctly viewed not as an independent branch of state policy, but as a whole set of family-oriented measures (Kamerman, Kahn, 1989: 582). These include, for example, tax, migration, educational and housing policies that directly affect family life.

In the European academic discourse the modern approach to the family policy is connected with the demand for sustainability (Family experiment, 2010: 3; Leitner et al., 2008), understood as the ability to respond flexibly both to the changing parameters of the environment and on the personal demands of individuals looking for a balance between the work and the life. The most essential task of the sustainable family policy is to preserve the viability of the family in the conditions of individualization, multiplication and de-standardization of its forms. Such a request to the family policy determines the importance of its detailed analysis in terms of its social and cultural coherence to the modern trends and the expectations of the society.

German experience gives the researcher wide opportunities to analyze the dynamic changes in the macro and micro level of the society as a result of the impact of different models of family policy. Germany is a unique example of the state, which provides the conditions for the natural experiment (Cooke, 2007: 934), being the result of combination of two different socio-economic systems of the FRG and the GDR, that are identical in national, cultural and linguistic dimensions, but evolved in different ideological, economic and socio-cultural environment for forty years. As a result, two opposite family and gender policies were formed, that, in turn, determined the nature of the dominant models of male and female biographies and patterns of interpersonal relationships (Duggan, 2010; Ziefle, Gangl, 2014). The analysis of the process and the results of German reunification allows to find out how families with different gender patterns in the distribution of tasks of paid and unpaid work react to the changes in the powerful discourse on the family and the roles of men and women in the society.

By the end of the twentieth century, Germany was a typical example of the state conducting the conservative family policy and maintain the traditional division of roles in the labor market and in the family (Lietzmann, 2014; Ziefle, Gangl, 2014). The gender division of duties in the family was determined by the practice of joint taxation, which was the most favorable in the case of families with single breadwinner, as well as generous benefits for housewives and the specific organization of the system of childcare and education (Sainsbury, 1999; Pettit, Hook, 2009; Korpi, Ferrarini and Englund, 2013).

Since the mid-2000s, in accordance with European trends, there are significant changes in the labour market and in the private family relations (Lewis et al., 2008) as a respond to the new Scandinavian-like state policy, which can be characterized as egalitarian and gender-sensitive, targeted at achieving the equality of rights and duties of men and women in the public and the private spheres (Spieß, Wrohlich, 2008; Ziefle, Gangl, 2014; Hofäcker et al., 2013; Lewis et al., 2008; Daly, 2011). Studying these processes reveals the mechanism of interaction between changing socio-political environment and more sustainable gender-cultural attitudes of the society (Pfau-Effinger, 2010).

\section{The Aim of the Research}

The aim of the research is to analyze, drawing on the methodology of the gender and comparative approaches, how contemporary German society responds to changes in the powerful family discourse, as well as to evaluate the effectiveness of the social and political measures aimed at supporting the egalitarian division of family duties between partners in modern Germany.

My analytical interest, on the one hand, is focused on the identification of specific national features in the formation of strategies for achieving the balance between the paid work and the family in Germany. At the same time, I aim at identifying the micro-social determinants that influence on the preference of particular patterns of the combination of the paid work and the care at the level of the household. I assume that the description of the mechanisms that contribute to a balance of the work and the care in Germany can be methodologically and instrumentally valuable for the analysis of social and family practices in other countries in both Western and Eastern Europe.

\section{Methods and Theoretical Approach}

The grounding theoretical principle of the research is a compound of the gender mainstreaming methodologies and the comparative cultural and historical research that enables volume vision of gender aspects of the social transformations in German society. Comparative historical studies enable to trace the dynamics and detect the prerequisite of the analyzed trends and events, as well as to offer a reasoned forecast of their further development. Drawing on the notion of Professor Olga Zdravomyslova, dealing with comparative cross-cultural studies is the only way to examine whether social 
and gender processes are inherent to global trends or whether they are to a greater extent the result of specific historical, cultural, or political circumstances (Zdravomyslova, 2008: 25).

The gender structure of German society is described and analyzed using the combination of methods of the structural functionalism and the social constructivism. The theory of the gender system is applied in the analysis of the external context of socially organized relations between men and women, and determine the gender roles and legitimate types of gender interactions and subordination, while the constructivist approach reveals the mechanisms of interaction and mutual influence of the structure and an individual (Chernova, 2013). The combination of these approaches enables analyzing the gender interactions at the micro and macro levels, which is essential for the research.

The comparative analysis of models of the family policy in Germany carried out on the basis of gender expertise of the official discourse and legislative documents regulating the relations of the family and the state, as well as through the analysis of secondary academic sources. The empirical evidence discussed in the work is a combination of the results of representative research, such as the German socio-economic panel (GSOEP) and qualitative biographical studies. The quantitative data is the source of statistics, while the qualitative methods are preferable when one analyzes the social transits, because they allow to monitor the various phases of development, fix the reaction of the society and individuals to changing environment, provide an access to the subjective reactions on certain events of their direct participants and observers.

\section{The Main Body of the Paper}

\subsection{The transformation of power and public discourse on family in Germany in 1945-2010}

The formation of the new states in the divided Germany as well as their family policies occurred in the context of overcoming the ravages of the war and the gradual return to the standardization of the life circle in the society (Corsten, 2001).

In 1945, the majority of Germans - both in the East and the West - is not considered the victors as the liberators; they were not interested in politics and were not involved in active struggle with the legacy of the national-socialism. At the individual level, the problems of war were articulated in the context of the personal loss of the family, friends and neighbors, as well as the crash of the previous values and attitudes. The society was not united by the sense of collective guilt or the condemnation of fascism, but, on the contrary, found itself in the process of self-actualization and individualization: after 1945, many people have tried to rewrite their biographies. The researchers point out that similar process took place in the eastern Länder of Germany after the fall of the Berlin Wall (Von Plato, 1993).

In such an atmosphere of de-politicization and social disintegration, the formation of new states of the GDR and the FRG went on, that quickly began to acquire specific features and in many ways opposed themselves openly to each other, including the approach to the family and the nature of gender relations in the society. Both states institutionalized strong political and legal systems (Vaterstaat), by declaring themselves as defenders of the interests of women, although based on different perceptions of what women really need (Ferree, 2012).

The equality of rights, which was originally given to German men and women in 1918, was enshrined again in the Basic Laws of the West and the East Germany. Then, however, a fundamentally different implementation of this principle in the family and the labor law was followed (Mazari, Gerhard, Wischermann, 2002).

The outcome was the formation of two contrasting models of family and labor relations: two-earner family model in the East Germany, in which a woman was expected to participate fully in the labor market along with the compulsory motherhood; and the conservative model of a male-breadwinner and a woman-housewife in the West Germany, which is based on the idea of women's specific gender role - different to a men's role in content but equal in the value to the society (Ostner, Schmitt, 2008; Chamberlayne, 1994).

German sociologist Mira-Marx Ferree draws attention to the asymmetry of gender relations in both systems and calls them the public and the private patriarchies (Ferree, 1996). The social contract in the GDR was based on the substantial support of the households by the state, which subsidized directly or indirectly about $80 \%$ of the child costs by the time of the fall of the Berlin Wall (Leitner et al., 2008), and thereby freed women to the active paid employment. The society responded to this policy in the form of high and early fertility among all European countries, while in the western part of the country the opposite demographic trends have been observed since the 1950s and virtually have not reacted to attempts to correct them.

The social security system of the FRG has been designed in such a way as to ensure maximum benefits for qualified and stable working man, performing the role of a husband, a father and a head of the family, and a woman who is functionally related to a family, a home and children (Pfaff, Roloff, 1990; Trappe, Rosenfeld, 2000). To put it in other 
words, the state was supported not individuals, but the statuses they occupy and obligations they perform - husband to his wife, parents to children, relatives and neighbors to each other (Leitner et al., 2008). The deviation from the desired standards led to economic sanctions and social deprivation, which was experienced by non-registered couples, single mothers and children born out of wedlock. The design of the system of the taxation, which was calculated together for the spouses and increased in case of the family's second source of income, as well as generous benefits for childcare, have excluded women from paid employment at least until the child reached three. Together, these measures were secured the dominant traditional male breadwinner and female housewife gender contracts and formed a gender-asymmetric nature of the politics of the FRG (Gustafsson, 1991; Sainsbury, 1999; Korpi, Ferrarini and Englund, 2013).

\subsection{The features and the results of German reunification in the macro and micro-social dimensions}

Forty years between the construction and destruction of the wall between East and West Germany significantly altered the social relationships in the society, which shared initially common national, historical and cultural patterns. Although united Germany has made significant steps towards gender assimilation (Künzler et al., 2001), even today the legacy of previous gender regimes is still visible at the level of the social structure and patterns of interpersonal behavior (Bauer, Dähner, 2010; Ebert et al., 2014).

For the GDR, the merger of two political and economic systems meant a complete transformation of the labor market and the socio-economic relations between the population and the state. The work-oriented society (Arbeitsgesellschaft) had to be replaced with more modern societal system based on the de-centralized power relations, flexible structure of the employment, and newly established information and service economy (Gleiser, 1996). The radical redistribution of the labor and the care, the resources and the income had a huge impact on the life of the entire society, although in various degrees: the losers of the combination turned out to be women who suddenly lost their economic independence, social guarantees and a number of civil rights (Mazari, Gerhard, Wischermann, 2002: 394; Behrend, Maynard and Purvis, 1996; Ostner, 1993, 1998; Duggan, 2010; Einhor, Gerhard, 1991-2; Kolinsky, 1992). For them, the reunification really meant a serious step back, the 'regression to pre-war gender roles' (Adler, 1997), in respect of loss of the status of the central object of numerous social benefits from the state.

The transfer of western models of social and family policies resulted in Eastern Germany women's displacement into the private sphere. The elimination of the state support system made impossible full economic participation for the mothers; in addition, the economic crisis led to a significant reduction in the number of childcare facilities in enterprises and substantial growth of the prices for their services due to the privatization of the public sector (Rindfuss, Brewster, 1996: 273; Adler, 1997: 44).

The reaction of the East Germans on the destruction of the life support system was immediate and sharp: from 1990 to 1992 the number of marriages and births in the new Länder halved. In 1992, the birth rate has reached a record low of 0.8 children per woman, and despite the fact that researchers observed a significant decline in fertility in all former socialist countries (Frejka, Sobotka, 2008; Billingsley, 2010), there was unprecedented case (Winkler, 1990; Goldstein, Kreyenfeld, 2011; Oliver, Mätzke, 2014). The attempts of the new authorities to stimulate monetary the situation proved to be ineffective in the absence of the other components of social security (Leitner et al., 2008).

'Children are now a question of money', - pointed an East German women (Bütov, 1992: 48), and a former civil engineer explained: 'In the GDR, women did not have to choose between having children and work. We had both and we never questioned having both. In the West, attitudes toward work and children were based on finances ... Now there is general uncertainty ... One knew how everything would develop in the future. [After unification], we were thrown into cold water and told to swim (Adler, 1997: 45-46).

Gradually, however, the federal government's investment in the eastern project (about 1.5 billion marks in 19901999) began to show the positive results. In 1992-1993, the crisis in the demographics had been overcome: the migration slowed down, the reproductive behavior recovered, although mainly in the West German family patterns.

The last decade of the twentieth century has brought changes in the life of a relatively stable society of the old federal states of Germany. Among the most notable trends is the growing number of working women, mainly due to the transition of housewives to the different patterns of underemployment (one-and-a-half-earner family; Lewis 2001: 145), often in the tertiary sector. Thus, there was a further spread of two-career model of the family economy, though, with maintaining the predominance of female workers in the private sphere and the male dominance in the public sphere (Leitner et al., 2008; Rosenfeld, Trappe and Gornick, 2004; Hanel, Riphahn, 2012). This pattern of gender relations was called modernized male breadwinner model (Pfau-Effinger, Sakac-Magdalenic 2010). 


\subsection{From conservatism to sustainability: current approaches to the family policy in modern Germany}

The formation of the current stage of family and labour policies in Germany took place in the context of forming a common legal space of the European Union. Article 2 of the Amsterdam Treaty defined the widespread promotion of equality of rights and opportunities for men and women as an objective for all EU-states. This entails, inter alia, the removal of legal and institutional barriers to gender equality in the labor market.

The period of 1998-2005, when the government of Social Democrats and Greens was being in office, the social and the family policy in Germany have undergone a distinct shift towards promoting active employment for the parents and empowerment for the children. Came to replace them a coalition of Social and Christian Democrats, led by Angela Merkel, intensifies the reforms of legal and institutional framework of domestic policy in the Scandinavian-like style (Ziefle, Gangl, 2014; Hofäcker et al., 2013; Lewis et al., 2008; Daly, 2011).

In 2005, the Merkel government presented an updated flexible scheme of paid parental leave. Since 2007, paid leave for childcare is reduced from 24 to 14 months, and at least two of them must be used by the father of a child. At the same time, secure employment cover the total period of paid and unpaid leave up to 36 months (Henninger, Wimbauer and Dombrowski, 2008). The researchers point out that the new program not only brings together the German family policy with the most effective models of Scandinavian countries, but also marks a return to the West and the East German models of 1970-1980s, when payments for working mothers (Mutterschaftsgeld) were dependent on the size of the previous earnings (Ziefle, Gangl, 2014; Hofäcker et al., 2013).

Like in the past, in 2000s women from the new lands, who tend to the combination of the employment and the motherhood, respond quickly and consistently to changes in the parental leave program (Ziefle, Gangl, 2014: 571). In addition, the number of men, who decided to take the parental leave, significantly increased (10.5\% in 2008), but more than half of them chose mandatory two months, and only about $2 \%$ took a full leave of 12 months (Henninger, Wimbauer and Dombrowski, 2008: 300). According to the Federal Office of Statistics, by mid-2009 there were $18 \%$ of men among all recipients of Elterngeld (Hatter et al., 2010: 10).

Between 2007 and 2014, the state invested about 5.4 billion euro in the infrastructure of child care (BMFSFJ 2013). It should have been allow to organize 780.000 places in childcare facilities and thus surpass the European directive by $5 \%$. As of 2013 , the real average figure reached $29.3 \%$, however with significant variations in the different parts of Germany according to the traditional dichotomy of 'the East - the West' in the patterns of childcare (Oliver, Mätzke, 2014; Goldstein, Kreyenfeld, 2011).

In recent years, researchers have undertaken attempts to assess comprehensively the position of women in modern Germany. Many of them argue the unevenness of power efforts in different policy areas, with the result that there is still a gender asymmetry in public relations. Thus, in German law and policy there are still rules that can be understood as a heritage of the conservative family policy aimed at supporting families with a single earner. For example, the tax system still favors households with one (or one-and-a-half) source of income, and so continues to play restrictive role for women's economical activity (Bäcker, Neuffer, 2012).

We can observe the advancement of women in power and employment, but there are still notable gender differences in education and subsequent career paths: compared with men, women are underrepresented in the engineering and technical specialties and in highly paid jobs in management. Typical jobs for women are still in serving and caring (Smyth, Steinmetz, 2008: 260). In monetary terms, the gender gap in the labor market in Germany is estimated at 22.8\%, which is one of the worst in Europe (Leschke, Jepsen, 2014). Four of the six political parties that are represented in the Bundestag, have implemented $25-50 \%$ quota for women and thus contributed to the promotion of gender equality at the highest level (Xydias, 2014). In March 2015, the Parliament approved the Law of 30\% representation of women in the top management of the largest German companies (Deutsche Welle 2015). The sum total of actions and reactions is the 11th place in the global ranking of countries that have achieved gender equality in 2013 (Bekhouch et al., 2013).

We now turn to the changes that the past decades have brought to the life of German society. What are the patterns of everyday life in modern Germany?

Domestic work, raising children, caring for the sick and elderly are still women's duties - free within the family ties and undervalued in the labour market (Rerrich, 1996; Henninger, Wimbauer and Dombrowski, 2008; Ebert et al., 2014). Given the increasing economic activity, women in German society often face with the phenomenon of the double burden, and the more resources they have the better they cope with the task of finding a work-life balance (Hofäcker et al., 2013). The networks of support of (partially) working mothers include older relatives and hired personnel that assisting them in the childcare and housekeeping. The patterns of desired upbringing of children involve the public institutions providing (often on a voluntary basis) various educational and leisure activities. The responsibilities of women are everyday 
organization and coordination of all family's interactions in time and space, as well as the adjustment and compensation of their failures. On a symbolic level they also realize the function of giving completeness, wholeness and connectedness of life of the whole family.

There is still difference between the East and the West of Germany in preferred patterns of the combination of the employment and the care. Mothers from the old federal lands prefer part-time employment and share more familyoriented views on the education of children (Konietzka, Kreyenfeld, 2010). In the East of the country women are active in both the labor market and in the use of the childcare facilities (Trappe, Sorensen, 2006), and this pattern is more common among the well-educated classes.

The 2008 was the first year in recent history in Germany, when the parity fertility between the west and the east of the country was established. The increase in the age of first motherhood is continuing: in 2001-2008, it has risen by one year. Women in the Eastern lands, however, have children one year earlier (27.5 in 2008), but since the beginning of the post-unification crisis the number of families with two children has not recovered yet (Frejka, Sobotka 2008). It is expected that the age cohort born in 1970 will become a turning point in the generation of all-German trends in fertility, then the fertility rate will begin to grow (Goldstein, Kreyenfeld, 2011).

\section{Conclusion}

The Public and scholarly debates about the modern transformations of the family and the parenthood are generally polarized (Williams, 2005). There are those who consider social changes as the negative effects of the general moral decline, disseminating the values of selfish individualism, careerism and consumerism, the devaluation of parental involvement and care, the loss of the mutual obligations of family members (Etzioni, 1993). Other social theorists, in contrast, interpret current trends of the individualization of the society in an optimistic perspective, stressing the transition from traditional gender division of roles to the formation of free and more equal biographical projects (Giddens, 2013; Beck, Beck-Gernsheim, 2014). The care and the education of the children have now a complex structure, taking into account the mutual interests and needs of all family members, including the state, voluntary and market-based organizations, and the social networks (Lewis, Daly, 2000).

In order to help families in the realization of their most important social functions, modern family policy should be a flexible and multi-faceted set of norms and activities that reflect the dynamics of the social changes, but also take into account the initial historical, cultural and gender context of the society (Chernova, 2013; see also Hochschild, 2003; Wierda-Boer et al., 2009). On the ideological level, it should be based on the recognition of the diversity of the society in terms of an individual's configuration of a biographical way, family values and reproductive patterns.

\section{Acknowledgement}

This study (research grant No 8.1.98.2015) was supported by The Tomsk State University Academic D.I. Mendeleev Fund Program in 2015.

\section{References}

Adler, M.A. (1997). Social change and declines in marriage and fertility in Eastern Germany. Journal of Marriage and the Family: 37-49. Adorno, T. W. (1956/1974). Satzzeichen.

Bäcker G. and S. Neuffer (2012). Von der Sonderregelung zur Beschäftigungsnorm: Minijobs im deutschen Sozialstaat. WSI Mitteilungen, 1: 13-21.

Bauer U. and S. Dähner (2010). Das volle Leben. Frauenkarrieren in Ostdeutschland. Berlin: Bundesministerium des Innern.

Beck, U., Beck-Gernsheim, E. (2014). Families in a runaway world. The Blackwell companion to the sociology of families: 499-514.

Behrend, H., Maynard, M. and J. Purvis (1996). East German Women Five Years after the Wende. New frontiers in women's studies: knowledge, identity and nationalism: 220-42.

Bekhouch, Y., Hausmann, R., Tyson, L.D. and S. Zahidi. (2013). The global gender gap report 2013. Geneva Switzerland World Economic Forum 2013.

Billingsley, S. (2010). The post-communist fertility puzzle. Population research and policy review, 29 (2): 193-231.

Bütow, B. (1992). Frauenerwerbsarbeit in den neuen Bundesländern und Anforderungen an Frauenpolitik am Beispiel von empirischen Ergebnissen einer soziologischen Studie aus Sachsen. Sozialwissenschaften und Berufspraxis, 15: 376-393.

Chamberlayne, P. (1994). Women and social policy. Social Policy in Germany: 173-190.

Cheal, D.J. (2008). Families in Today's World: Comparative Approach. - New York.

Chernova, Zh. (2013). Gender Analysis of the family policy in contemporary Russia: the features and trends [Gendernyi analiz semejnoj politiki v sovremennoi Rossii]. Saratov. 
Connell, R. (1987). Gender and Power. Society, the Person and Sexual Politics. - Cambridge: Polity Press.

Cooke, L.P. (2007). Persistent policy effects on the division of domestic tasks in reunified Germany. Journal of Marriage and Family, 69 (4): $930-950$.

Corsten, M. (2001). Commentary: Sociological Images of Modern Germany. International Journal of Politics, Culture, and Society, 15 (2): 379-393.

Daly, M. (2011). What adult worker model? A critical look at recent social policy reform in Europe from a gender and family perspective. Social politics: international studies in gender, state \& society, 18 (1): 1-23.

Deutsche Welle, (2015). Bundestag prinyal zakon o zhenskikh kvotakh. [Online] Awailable: http://www.dw.de/бундестаг-принял-законо-женских-квотах/а-18299782 (March 6, 2015).

Duggan, L. (2010). Restacking the deck: family policy and women's fall-back position in Germany before and after the unification. Feminist Economics, 1(1): 175-194.

Ebert, I.D., Steffens, M.C. and A. Kroth (2014). Warm, but maybe not so competent?-Contemporary implicit stereotypes of women and men in Germany. Sex roles, 70 (9-10): 359-375.

Etzioni, A. (1993). The Parenting Deficit - London, Demos.

Family Experiment (2010). Deutsches Jugendinstitut Bulletin. - München.

Ferree, M.M. (1996). Sociological perspectives on gender in Germany. Women in German Yearbook, 12: 27-38.

Ferree, M.M. (2012). Varieties of Feminism: German gender Politicsin Global Perspective - CA: Stanford University Press.

Frejka, T. and T. Sobotka (2008). Overview Chapter 1: Fertility in Europe: Diverse, delayed and below replacement. Demographic research, 19 (3): 15-46.

Gerhard, U. (1991-2). German Women and the Social Costs of Unification. German Politics and Society, 24 (5): 16-33.

Giddens, A. (2013). The transformation of intimacy: Sexuality, love and eroticism in modern societies. - John Wiley \& Sons.

Gleiser, S. (1996). Der Arbeitsmarkt für Akademiker. Die Zukunft der Akademikerbeschäftigung: 11-45.

Goldstein, J.R. and M. Kreyenfeld (2011). Has East Germany Overtaken West Germany? Recent Trends in Order-Specific Fertility. Population and Development Review, 37 (3): 453-472.

Gustafsson, S. (1991). Separate taxation and married women's labour supply. Journal of Population Economics, 5: 61-85.

Hanel, B. and R.T. Riphahn (2012). The employment of mothers-recent developments and their determinants in East and West Germany. Jahrbücher für Nationalökonomie und Statistik: 146-176.

Henninger, A., Wimbauer, C. and R. Dombrowski (2008). Geschlechtergleichheit oder exklusive Emanzipation?

Ungleichheitssoziologische Implikationen der aktuellen familienpolitischen Reformen. Berliner Journal für Soziologie, 18 (1): $99-128$.

Hochschild, A.R. (2003). The Second Shift. - New York: Penguin Books.

Hofäcker, D., Stoilova, R. and J.R. Riebling (2013). The gendered division of paid and unpaid work in different institutional regimes: Comparing West Germany, East Germany and Bulgaria. European sociological review, 29 (2): 192-209.

Janczyk, S., Correll, L. and A. Lieb (2003). Quo vadis Arbeit? Jenseits verengter Perspektiven und Deutungsmuster, Discussion Papers 1, Marburg: GendA - Netzwerk feministische Arbeitsforschung.

Kamerman, S.B. and A.J. Kahn (1989). The normative/ideological context of policy formation: Has the United States learned from Europe? Review of Policy Research, 8 (3): 581-598.

Klammer, U. et al. (2000). WSI Frauen Daten Report. Handbuch zur wirtschaftlichen und sozialen Situation von Frauen. - Berlin: Edition Sigma.

Kolinsky, E. (ed., 1992). The Federal Republic of Germany: The end of an era. - Bloomsbury Academic, 1.

Konietzka, D. and M. Kreyenfeld (2010). The growing educational divide in mothers' employment: an investigation based on the German micro-censuses 1976-2004. Work, Employment \& Society, 24 (2): 260-278.

Korpi, W., Ferrarini, T. and S. Englund (2013). Women's opportunities under different family policy constellations: gender, class, and inequality tradeoffs in western countries re-examined. Social Politics: International Studies in Gender, State \& Society, 20 (1): 140.

Künzler, J. et al. (2001). Gender division of labour in unified Germany. - Le Tilburg: WORC.

Lange, A. and K. Jurczyk (2010). The Globalized Family. In: Family Experiment. Deutsches Jugendinstitut Bulletin. - München.

Leitner, S., Ostner, I. and C. Schmitt (2008). Family policies in Germany: 175-202. - VS Verlag für Sozialwissenschaften.

Leschke, J. and M. Jepsen (2014). Is the Economic Crisis Challenging the Prevailing Gender Regime? A Comparison of Denmark, Germany, Slovakia, and the United Kingdom. Social Politics: International Studies in Gender, State \& Society, 21 (4): $485-508$.

Lewis, J. (2001). The End of Marriage? Individualism and Intimate Relationships - Cheltenham, Edward Elgar.

Lewis, J. and M. Daly (2000). The concept of social care and the analysis of contemporary welfare states. British Journal of Sociology, 51 (2): 281-298.

Lewis, J. et al. (2008). Patterns of development in work/family reconciliation policies for parents in France, Germany, the Netherlands, and the UK in the 2000s. Social Politics: International Studies in Gender, State \& Society, 15 (3): 261-286.

Lietzmann, T. (2014). After recent policy reforms in Germany: Probability and determinants of labour market integration of lone mothers and mothers with a partner who receive welfare benefits. Social Politics: International Studies in Gender, State \& Society, 21 (4): 585-616.

Mazari, S., Gerhard, U. and U. Wischermann (2002). Germany. In: Griffin G. (ed.). Women's employment, women's studies and equal opportunities 1945-2001: reports from nine European countries. - Ulrike Helmer Verlag.

Oliver, R.J. and M. Mätzke (2014). Childcare Expansion in Conservative Welfare States: Policy Legacies and the Politics of 
Decentralized Implementation in Germany and Italy. Social Politics: International Studies in Gender, State \& Society, 21 (2): 167193.

Ostner, I. (1993). Slow motion: women, work and the family in Germany. Women and social policies in Europe: Work, family and the state, 92: 110-12.

Ostner, I. (1998). The politics of care policies in Germany. In Lewis, J. (Ed.): Gender, Social Care and Welfare State Restructuring in Europe: 111-174. - Aldershot, Ashgate.

Ostner, I. and C. Schmitt (2008). Family Policies in the context of Family Change. The Nordic Countries in Comparative Perspective. Wiesbaden: VS.

Pettit, B. and J.L. Hook (2009). Gendered Tradeoffs: Family, Social Policy, and Economic Inequality in Twenty One Countries. - New York: Russell Sage Foundation.

Pfaff, A.B. and J. Roloff (1990). Familienpolitik in der Bundesrepublik Deutschland: Gewinn oder Verlust für die neuen Bundesländer. Ifg Frauenforschung, 4 (90).

Pfau-Effinger, B. (1998). Gender cultures and the gender arrangement - a theoretical framework for cross-national comparisons on gender. Innovation: the European Journal of Social Sciences, 11: 147-166.

Pfau-Effinger, B. (2010). Cultural and institutional contexts. Dividing the domestic. Men, women and household work in cross-national perspective: $125-146$.

Pfau-Effinger, B. and S. Sakac-Magdalenic (2010). Informal employment in the work-welfare arrangement of Germany. - London: Routledge.

Rerrich, M.S. (1996). Modernizing the Patriarchal Family in West Germany Some Findings on the Redistribution of Family Work between Women. European Journal of Women's Studies, 3 (1): 27-37.

Rindfuss, R.R. and K.L. Brewster (1996). Childrearing and fertility. Population and Development Review: 258-289.

Rosenfeld, R.A., Trappe, H. and J.C. Gornick (2004). Gender and work in Germany: Before and after reunification. Annual Review of Sociology: 103-124.

Rozhdestvenskaya, E. (2012). Biography as a social phenomenon and an object of sociological analysis [Biografija kak socialnyi fenomen i object socialnogo analiza]. Moscow.

Sainsbury, D. (1999). Gender, policy regimes, and politics. In Sainsbury, D. (Ed.), Gender and the Welfare State: 245-275. - New York: Oxford University Press.

Smyth, E. and S. Steinmetz (2008). Field of study and gender segregation in European labour markets. International Journal of Comparative Sociology, 49 (4-5): 257-281.

Spieß, C.K. and K. Wrohlich (2008). The parental leave benefit reform in Germany: costs and labour market outcomes of moving towards the Nordic Model. Population Research and Policy Review, 27: 575-591.

Stoilova, R., Riebling, J. and D. Hofäcker (2011). Division of paid and unpaid work - Patterns of Social Inequality: A comparison of Germany, Bulgaria, France and Hungary, TransEurope Working Paper, 34. - Bamberg: University of Bamberg.

Trappe, H. and A. Sorensen (2006). Economic relations between women and their partners: an East and West German comparison after reunification. Feminist Economics, 12(4), 643-665.

Trappe, H. and R.A. Rosenfeld (2000). How do children matter? A comparison of gender earnings inequality for young adults in the former East Germany and the former West Germany. Journal of Marriage and Family, 62 (2): 489-507.

Von Plato, A. (1993). An Unfamiliar Germany: Some Remarks on the Past and Present Relationship between East and West Germans. Oral History: $35-42$.

Wierda-Boer, H.H. et al. (2009). Combination strategies and work-family interference among dual-earner couples in Finland, Germany, and the Netherlands. Community, Work and Family, 12 (2): 233-249.

Williams, F. (2005). Rethinking Families. - Calouste Gulbenkian Foundation, UK, London.

Winkler, G. (1990). Frauenreport 90. - Berlin: Verlag Die Wirtschaft.

Xydias, C. (2014). Women's Rights in Germany: Generations and Gender Quotas. Politics \& Gender, 10 (01): 4-32.

Zdravomyslova, O. (2008). Gender aspects of modern Russian transformations: Problems of the research methodology [Gendernye aspekty sovremennykh rossijskikh transformaciy: problemy metodologii issledovaniya]. Moscow.

Ziefle, A. and M. Gangl (2014). Do Women Respond to Changes in Family Policy? A Quasi-Experimental Study of the Duration of Mothers' Employment Interruptions in Germany. European Sociological Review, 30 (5): 562-581. 